\title{
Peramalan Kebutuhan Air Untuk Penyiapan Lahan Menggunakan Metode Siklis (Studi Kasus Daerah Irigasi Bendungan Batu Bulan Kec.Moyo Hulu)
}

\author{
Koko Hermanto ${ }^{1}$, Silvia Firda Utami ${ }^{2}$ \\ ${ }^{1}$ UniversitaasTeknologi Sumbawa,koko.hermanto@uts.ac.id \\ ${ }^{2}$ Universitas Teknologi Sumbawa, silvia.firda.utami@uts.ac.id
}

\begin{abstract}
The area of agriculture in the Moyo Hulu sub-district of Sumbawa Regency is 6000 hectares with irrigation water sources from Batu Bulan Dam, which is the largest dam in Sumbawa Regency with an area of 932 hectares. Considering that Sumbawa Regency is one of the regions with a high level of drought, information on irrigation water requirements for land preparation needs to be known because it can optimize the allocation of the use of dam water discharge. And one of the important stages needed in the planning and management of irrigation systems. Based on this, the aim of this study is to forecast water requirements for land preparation in the irrigation area of Batu Bulan Dam by using cyclical methods because the data patterns are cyclical or seasonal. The factors that influence water requirements for preparing agricultural land are topography, hydrology, climatology and soil texture. From these factors, the data is then analysed so that the volume of water preparation needs to be obtained every month so that the results of the analysis can be predicted for the next period.
\end{abstract}

Keyword: Forecasting, Cyclic methods, water requirements for land preparation, irrigation, agriculture.

\begin{abstract}
Abstrak. Luas area pertanian di kecamatan Moyo Hulu Kabupaten Sumbawa sebesar 6000 hektar dengan sumber air irigasi dari Bendungan Batu Bulan yang merupakan bendungan terbesar di Kabupaten Sumbawa dengan luas 932 hektar. Mengingat Kabupaten Sumbawa salah satu wilayah dengan tingkat kekeringan yang cukup tinggi maka Informasi kebutuhan air irigasi untuk penyiapan lahan perlu diketahui karena dapat mengoptimalkan pengalokasian pengunaan debit air bendungan. Serta salah satu tahap penting yang diperlukan dalam perencanaan dan pengelolaan sistem irigasi. Berdasarkan hal tersebut tujuan dari penelitian ini adalah meramalkan kebutuhan air untuk penyiapan lahan di daerah irigasi Bendungan Batu Bulan dengan menngunakan metode siklis karena pola datanya bersifat siklis atau musiman. Adapun faktor-faktor yang mempengaruhi kebutuhan air untuk penyiapan lahan pertanian adalah topografi, hidrologi, klimatologi dan tekstur tanah. Dari datadata faktor tersebut selanjutnya dianalisa sehingga diperoleh volume kebutuhan air penyiapan lahan setiap bulannya sehingga dari hasil analisa tersebut dapat diramalkan untuk periode berikutnya.
\end{abstract}

Keyword: Peramalan, metode Siklis,Kebutuhan air penyiapan lahan, irigasi, pertanian. 


\section{Pendahuluan}

Dalam memenuhi kebutuhan air khususnya untuk kebutuhan air di persawahan maka perlu didirikan sistem irigasi dan pembangunan bendungan. Salah satu bendungan yang sudah dibangun di Kabupaten Sumbawa, Provinsi Nusa Tenggara Barat (NTB) adalah Bendungan Batu Bulan, bendungan ini mempunyai luas 932 ha terletak di Batu Bulan Kecamatan Moyo Hulu. Bendungan Batu Bulan saat ini tercatat sebagai waduk terbesar dan terpanjang di provinsi NTB, dengan panjang puncak bendungan total $2.750 \mathrm{~m}$. bendungan ini terbentuk dengan membendung lembah sungai sungai Moyo, sunngai Sebasang, ungai Rea dan sungai Lito, yang dapat dimanfaatkan sebagai penyedia air irigasi persawahan, pembangkit tenaga listrik, pengendali banjir, pariwisata, perikanan budidaya dan perikanan tangkap. Bendungan ini mulai dibangun tahun 1999-2002. Bendungan Batu Bulan mampu mengairi lebih dari 5500 Ha sawah di kecamatan Moyo Hilir dan Moyo Utara, selain itu masyarakat di sekitar waduk meliputi desa Mokong, Batu Bulan, Sebasang dan Batu Tering memanfaatkan waduk ini sebagai sumber penghasilan sampingan dengan usaha ikan Nila. Puluhan sampan dan keramba dalam bendungan menjadi atraksi tersendiri bagi wisatawan yang dating, dan tentu saja pengunjung dapat dengan bebas memanfaatkan kesempatan untuk olah raga memancing. Pengelolahan Waduk Batu Bulan dikelolah oleh pemerintah pusat.

Mengingat Kabupaten Sumbawa merupakan daerah yang mengalami musim kemarau yang sangat panjang, maka perlu adanya usaha untuk menghemat penggunaan persediaan air yang tersedia salah satunya adalah mengetahui kebutuhan air untuk penyiapan lahan. Karena ketersediaan air adalah faktor yang penting untuk keberlangsungan sistem pertanian. Dengan mengetahui kebutuhan air dapat memberikan gambaran kepada instansi terkait mengenai berapa debit air yang perlu disalurkan dari bendungan untuk kegiatan irigasi. Untuk mengetahui kebutuhan debit air untuk penyiapan lahan perlu dilakukan analisis data. Adapun data yang diperlukan pada penelitian ini berupa data klimatologi Sembilan tahun terakhir, selanjutnya dilakukan peramalan untuk mengetahui kebutuhan air untuk penyiapan lahan pada periode tahun berikutnya. Metode peramalan yang digunakan adalah metode siklis, dimana variabel terikatnya (Y) adalah volume kebutuhan air untuk penyiapan lahan sedangkan bulan merupakan variabel bebasnya $(\mathrm{X})$.

\section{Tinjauan Pustaka}

Irigasi didefinisikan sebagai pemberian air untuk memenuhi kebutuan air bagi tanaman. Pekerjaan irigasi meliputi penampungan dan pengambilan air dari sumbernya, mengalirkannya melalui saluran-saluran ke lahan pertanian dan pembuangan kelebihan air ke saluran pembuangan. Tujuan irigasi adalah memberikan tambahan (supplement) air terhadap air hujan dan memberikan air untuk tanaman dalam jumlah yang cukup dan pada saat dibutuhkan. Irigasi pada lahan sawah dimaksudkan untuk menjenuhkan tanah agar diperoleh struktur lumper yang baik bagi pertumbuhan tanaman padi, memenuhi kebutuhan air tanam, kebutuhan penggenangan, dan mengganti air di saluran.

Kegiatan penyiapan lahan merupakan kegiatan pengolahan tanah yang dilakukan pada awal sekali sebelum kegiatan tananm. Kegiatan ini dilakukan agar tanah sawah menjadi jenuh air sehingga perkolasi yang terjadi akibat lolosnyaair 
ke bawah permukaan tanah dapat diminimalkan (Mulya, 2018). Untuk perhitungan kebutuhan air irigasi selama penyiapan lahan, digunakan metode yang dikembangkan oleh Van de Goor dan Zijlsha (1968). Metode tersebut didasarkan pada laju air konstan dalam lt/dt/ha selama periode penyiapan lahan dan menghasilkan rumus sebagai berikut :

$$
L P=M\left(\frac{e^{k}}{e^{k}-1}\right)
$$

Dimana:

LP : Kebutuhan air untuk penyiapan lahan ( $\mathrm{mm} / \mathrm{hari})$

$\mathrm{M}$ : Kebutuhan air untuk mengganti kehilangan air akibat evaporasi dan perlokasi di sawah

yang telah dijenuhkan, dimana $M=$ Eo $+\mathrm{P}(\mathrm{mm} / \mathrm{hari})$

$\mathrm{P} \quad$ : Perkolasi (mm/hari)

Eo : Evaporasi terbuka $=1,1 \times$ Eto $(\mathrm{mm} / \mathrm{hari})$

$\mathrm{k}=\mathrm{M}\left(\frac{\mathrm{T}}{\mathrm{S}}\right)$

e : koefisien

Evaporasi atau disebut juga dengan penguapan adalah peristiwa berubahnya airmenjadi uap dan bergerak daripermukaan tanah dan permukaan air ke udara (Sorodarsono, 1976). Dalam penelitian ini besarnya nilai evaprasi ditentukan dengan menggunakan persamaan sebagai berikut.

$$
E T_{o}=c\{W \cdot R n+(1-W) \cdot f(u) \cdot(e a-e d)\}
$$

Dimana:

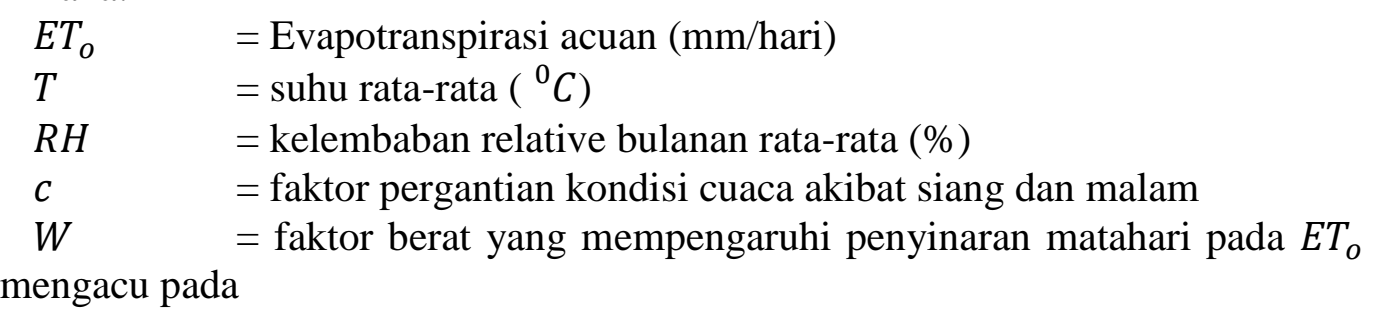
(mengacu pada

tabel Penman hubungan antara temperature dengan ketinggian)

$(1-W) \quad=$ faktor berat sebagai pengaruh angina dan kelembaban pada $E T_{o}$

$(e a-e d)=$ perbedaan tekanan uap air jenuh dengan tekanan uap nyata

\begin{tabular}{|c|c|}
\hline & $(e d=e a \times R H)$ \\
\hline$R n$ & $=$ radiasi penyinaran matahari $(\mathrm{mm} / \mathrm{hari})=R n s-R n 1$ \\
\hline Rns & $=$ Harga netto gelombang pendek $=R s(1-\alpha)$ \\
\hline$\alpha$ & $=$ keoefisien pemantulan $=0,25$ \\
\hline$R s$ & $=\left(0,25+0,5\left(\frac{n}{N}\right)\right) \times R a$ \\
\hline$R a$ & $=$ Radiasi extra terrensial \\
\hline $8 n$ & $=2,01 \times 10^{9} \cdot T^{4}\left(0,34-0,044 e d^{0,5}\right)(0,1+0,9 \cdot n / N)$ \\
\hline$(u)$ & $=0,27 \times(1+u .0,864)$ \\
\hline
\end{tabular}
(mbar) 
Salah satu metode peramalan yang digunakan untuk menentukan debit air untuk penyiapan lahan pada periode selanjutnya metode peramalan siklis. Dimana fungsi peramalan metode siklis dapat dilihat pada persamaan (3).

$$
Y=a+b \sin \frac{2 \pi X}{n}+c \cos \frac{2 \pi X}{n}
$$

Dimana variabel $X$ merupakan variabel bebas sedangkan $Y$ merupakan variabel terikat. Untuk mengetahui tingkat akurasi peramalan dapat menggunakan persaman (4) berikut.

$$
\text { Akurasi }=\frac{\sum \text { Angka Benar }}{\sum \text { Angka Pengujian }} \times 100 \%
$$

\section{Metodologi Penelitian}

\subsection{Data}

Data yang dibutuhkan untuk meramalkan kebutuhan air irigasi dalam penyiapan lahan adalah data sekunder yang diperoleh dari Badan Meteorologi, Klimatoli dan Geofisika (BMKG) Kabupaten Sumbawa berupa data klimatologi selama 9 tahun terakhir di kecamatan Moyo Hulu Kabupaten Sumbawa. Data-data klimatologi tersebut berupa data suhu, lama penyinaran matahari, kecepatan angina dan kelembaban. Pada Tabel 1 disajikan data tersebut yaitu rata-rata data klimatologi kecamatan Moyo Hulu 2010-2018.

\begin{tabular}{|c|c|c|c|c|c|c|c|c|c|c|c|c|c|c|}
\hline \multirow{2}{*}{ No. } & \multirow{2}{*}{ Jenis Data } & \multirow{2}{*}{ Satuan } & \multicolumn{12}{|c|}{ Bulan } \\
\hline & & & Jan & Feb & Mar & Apr & Mei & Juni & Juli & Agu & Sep & Okt & Nov & Des \\
\hline 1 & Suhu & ${ }^{0} \mathrm{C}$ & 26.44 & 26.50 & 26.70 & 27.01 & 27.23 & 26.57 & 26.08 & 26.19 & 26.80 & 28.28 & 28.19 & 27.18 \\
\hline 2 & $\begin{array}{l}\text { Kelembaban } \\
\text { Relatif }\end{array}$ & $\%$ & 86.97 & 86.61 & 85.50 & 81.92 & 79.40 & 75.83 & 73.96 & 70.24 & 70.37 & 71.51 & 77.97 & 84.40 \\
\hline 3 & $\begin{array}{l}\text { Lama } \\
\text { Penyinaran }\end{array}$ & $\%$ & 58.46 & 67.89 & 71.25 & 83.36 & 85.94 & 89.15 & 88.44 & 96.10 & 96.84 & 93.63 & 73.11 & 63.79 \\
\hline 4 & $\begin{array}{l}\text { Kecepatan } \\
\text { Angin }\end{array}$ & $\mathrm{m} / \mathrm{s}$ & 2.30 & 2.34 & 2.21 & 2.06 & 2.04 & 2.52 & 2.82 & 2.94 & 2.77 & 2.70 & 2.34 & 2.00 \\
\hline
\end{tabular}

Tabel 1. Rata-rata Data Klimatologi Kecamatan Moyo Hulu 2010-2018.

Sumber: Dinas BMKG Kabupaten Sumbawa telah dihitung

\subsection{Definisi Variabel}

1. Variabel Devenden $(Y)$

$Y=$ debit air yang dibutuhkan dalam penyiapan lahan daerah irigasi

kecamatan Moyo Hulu dengan dengan satuan $\mathrm{mm} / \mathrm{hari}$ atau satuan liter $/ \mathrm{m}^{2} /$ hari

2. Variabel Independen $(X)$

$X=$ variabel bulan, yaitu dimulai dari bulan Januari sampai Desember. 


\subsection{Teknik Analisis Data}

Teknik analis data untuk meramalkan kebutuhan air untuk penyiapan lahan pada penelitian ini adalah sebagai berikut.

1. Menentukan rata-rata data klimatologi sembilan tahun terakhir setiap bulannya;

2. Perhitungan nilai evapotranspirasi acuan $\left(E T_{o}\right)$ setiap bulannya dengan menggunakan persamaan (2);

3. Perhitungan volume kebutuhan air dalam penyiapan lahan $(L P)$ dengan menggunakan persamaan (1);

4. Analisis sebaran pola data $L P$;

5. Meramalkan volume kebutuhan air penyiapan lahan untuk periode berikutnya dengan menggunakan metode siklis dengan menggunakan persamaan (3);

6. Menentukan nilai Akurasi dengan persamaan (4);

7. Menarik kesimpulan;

\section{Hasil dan Pembahasan}

Berdasarkan data yang pada tabel 1 maka dapat dilakukan perhitungan evaporasi potensial dengan menggunakan persamaan (2). Adapun langkahlangkah perhitunganya pada bulan Januari adalah sebagai berikut:

Lokasi $=8^{0} 39^{\prime} 03^{\prime \prime}$ LS dan $117^{0} 25^{\prime} 47^{\prime \prime}$ BT

Suhu rata-rata

$=26,44{ }^{0} \mathrm{C}$

Kelembaban Relatif (RH) $=86,97 \%$

Lama penyinaran matahari $(\mathrm{n} / \mathrm{N})=58,46 \%$

Kecepatan angina $(\mathrm{u}) \quad=2,30 \mathrm{~m} / \mathrm{s}$

Langkah-langkah menentukan nilai evaporasi:

Langkah 1: Mencari nilai Tekanan Uap Jenuh (ea)

$\mathrm{T}=26,44{ }^{0} \mathrm{C}$ maka diperoleh nilai ea $=34,42$; (tabel hubungan suhu dengan nilai ea)

Langkah 2: Mencari nilai Faktor (W) dan (1-W)

$\mathrm{T}=26,44{ }^{0} \mathrm{C}$ maka diperoleh nilai $\mathrm{W}=0,759$ dan $(1-\mathrm{W})=0,241 ;$ (tabel hubungan suhu dengan nilai $W$ )

Langkah 3: Mencari nilai Koreksi Terhadap Temperatur (f(T))

$\mathrm{T}=26,44{ }^{0} \mathrm{C}$ maka diperoleh nilai $\mathrm{f}(\mathrm{T})=15,98 ;$; (tabel hubungan suhu dengan nilai $f(T))$

Langkah 4: Mencari nilai Tekanan Uap Nyata (ed)

ed $=$ ea $\times \mathrm{RH}=34,42 \times 86,97 \%=29,93 \mathrm{mbar}$

Langkah 5: mencari nilai fungsi ed (f(ed))

$\mathrm{f}(\mathrm{ed})=0,34-0,044\left(\mathrm{ed}^{0,5}\right)$

$\mathrm{f}(\mathrm{ed})=0,34-0,044\left(29,93^{0,5}\right)$

$\mathrm{f}(\mathrm{ed})=0,10$

Langka 6: menentukan niali Radiasi Eksternal (Ra)

Lokasi berada pada $8^{0} 39^{\prime} 03^{\prime \prime}$ LS sehingga diperolehnilai $\mathrm{Ra}=16,1 \mathrm{~mm} / \mathrm{hari}$;

(tabel hubungan garis lintang dengan nilai $R a$ )

Langkah 7: Menghitung nilai Radiasi Gelombang Pendek (Rs)

$\mathrm{Rs}=(0,25+0,54 . \mathrm{n} / \mathrm{N}) \mathrm{Ra}$ 
Rs $=(0,25+0,54 \times 58,46 \%) 16,1$

Rs $=9,11 \mathrm{~mm} / \mathrm{hari}$

Langkah 8: Mencari nilai Netto Gelombang Pendek (Rns)

Rns $=(1-a)$ Rs, $a=0,25$

Rns $=(1-0,25) 9,11$

Rns $=6,83 \mathrm{~nm} / \mathrm{hari}$

Langkah 9: Mencari nilai fungsi lama penyinaran matahari $(\mathrm{f}(\mathrm{n} / \mathrm{N}))$

$\mathrm{f}(\mathrm{n} / \mathrm{N})=0,1+0,9 \times \mathrm{n} / \mathrm{N}$

$\mathrm{f}(\mathrm{n} / \mathrm{N})=0,1+0,9 \times 58,46 \%$

$\mathrm{f}(\mathrm{n} / \mathrm{N})=0,63$

Langkah 10: mencari nilai FungsiAngin (f(u))

$\mathrm{f}(\mathrm{u})=0,27\{1+(\mathrm{u} \times 0,864)\}$

$f(u)=0,27\{1+(2,30 \times 0,864)\}$

$\mathrm{f}(\mathrm{u})=0,81$

Langkah 11: Mencari nilai Radiasi Netto Gelombang Panjang (Rn1)

$\mathrm{Rn} 1=\mathrm{f}(\mathrm{T}) \times \mathrm{f}(\mathrm{ed}) \times \mathrm{f}(\mathrm{n} / \mathrm{N})$

$\mathrm{Rn} 1=16,02 \times 0,10 \times 0,63$

$\mathrm{Rn} 1=1,00 \mathrm{~mm} / \mathrm{hari}$

Langkah 12: Mencari nilai Radiasi Netto (Rn)

$\mathrm{Rn}=\mathrm{Rns}-\mathrm{Rn} 1$

$\mathrm{Rn}=6,83-1,00$

$\mathrm{Rn}=5,83$

Langkah 13:Menghitung nilai Evapotranspirasi Potensial (Eto)

Dengan faktor koreksi $(\mathrm{c})=1,10 ;$ (Tabel angka koreksi Penmam)

Eto $=\mathrm{c}\{\mathrm{W} \cdot \mathrm{Rn}+(1-\mathrm{W}) \cdot \mathrm{f}(\mathrm{u}) \cdot(\mathrm{ea}-\mathrm{ed})\}$

Eto $=1,10\{0,76 \times 5,83+0,24 \times 0,81 \times(34,42-29,93)\}$

Eto $=5,83 \mathrm{~mm} /$ hari

Dengan cara yang sama seperti perhitungan di atas maka diperoleh perhitungan evapotranspirasi selama satu tahun yang disajikan pada tabel 2 berikut.

Tabel 2. Perhitungan Evapotransiprasi Bulanan dengan Metode Penman Modifikasi Rerata Tahun 2010-2018

\begin{tabular}{|c|c|c|c|c|c|c|c|c|c|c|c|c|c|c|c|}
\hline \multirow{2}{*}{ No } & \multirow{2}{*}{ Uraian } & \multirow{2}{*}{ Satuan } & \multirow{2}{*}{ Ket. } & \multicolumn{12}{|c|}{ Bulan } \\
\hline & & & & Jan & Feb & Mar & Apr & Mei & Jun & Jul & Ags & Sep & Okt & Nov & Des \\
\hline 1 & Temperatur Udara $(\mathrm{T})$ & $\mathrm{C}$ & Data & 26.44 & 26.50 & 26.7 & 27.01 & 27.23 & 26.57 & 26.08 & 26.19 & 26.80 & 28.28 & 28.19 & 27.18 \\
\hline 2 & $\mathrm{Ea}$ & Mbar & Tabel & 34.42 & 34.42 & 35.25 & 35.25 & 36.09 & 32.83 & 33.62 & 34.02 & 35.25 & 38.25 & 38.25 & 36.09 \\
\hline 3 & $\mathrm{~W}$ & & Tabel & 0.76 & 0.76 & 0.76 & 0.77 & 0.77 & 0.76 & 0.76 & 0.76 & 0.76 & 0.78 & 0.78 & 0.77 \\
\hline 4 & $1-\mathrm{W}$ & & Hitungan & 0.24 & 0.24 & 0.24 & 0.23 & 0.23 & 0.24 & 0.24 & 0.24 & 0.24 & 0.22 & 0.22 & 0.23 \\
\hline 5 & $f(T)$ & & Tabel & 16.02 & 15.98 & 16.02 & 16.3 & 16.26 & 16.1 & 16.02 & 15.98 & 16.26 & 16.5 & 16.42 & 16.26 \\
\hline 6 & Kelembaban Relatif (RH) & $\%$ & Data & 86.97 & 86.61 & 85.50 & 81.92 & 79.40 & 75.83 & 73.96 & 70.24 & 70.37 & 71.51 & 77.97 & 84.40 \\
\hline 7 & $\mathrm{ed}=\mathrm{ea} \times \mathrm{RH}$ & & Hitungan & 29.93 & 29.81 & 30.14 & 28.88 & 28.66 & 24.90 & 24.86 & 23.90 & 24.80 & 27.35 & 29.82 & 30.46 \\
\hline 8 & $\mathrm{f}(\mathrm{ed})=0,34-0,044\left(\mathrm{ed}^{\wedge} 0,5\right)$ & & Hitungan & 0.10 & 0.10 & 0.10 & 0.10 & 0.10 & 0.12 & 0.12 & 0.12 & 0.12 & 0.11 & 0.10 & 0.10 \\
\hline 9 & Letak Lintang Daerah & LS & Data & 8.39 & 8.39 & 8.39 & 8.39 & 8.39 & 8.39 & 8.39 & 8.39 & 8.39 & 8.39 & 8.39 & 8.39 \\
\hline 10 & $\mathrm{Ra}$ & $\mathrm{mm} / \mathrm{hari}$ & Tabel & 16.1 & 16.1 & 15.5 & 14.4 & 13.1 & 12.4 & 12.7 & 13.7 & 14.9 & 15.8 & 16 & 16 \\
\hline
\end{tabular}




\begin{tabular}{|c|c|c|c|c|c|c|c|c|c|c|c|c|c|c|c|}
\hline 11 & Radiasi Matahari (n/N) & $\%$ & Data & 58.46 & 67.89 & 83.36 & 83.36 & 85.94 & 89.15 & 88.44 & 96.10 & 96.84 & 93.63 & 73.11 & 63.79 \\
\hline 12 & $\mathrm{Rs}=(0,25+0,54 * \mathrm{n} / \mathrm{N}) \mathrm{Ra}$ & & Hitungan & 9.11 & 9.93 & 10.85 & 10.08 & 9.35 & 9.07 & 9.24 & 10.53 & 11.52 & 11.94 & 10.32 & 9.51 \\
\hline 13 & Rns $=(1-\mathrm{a}) \mathrm{Rs}, \mathrm{a}=0,25$ & & Hitungan & 6.83 & 7.45 & 8.14 & 7.56 & 7.02 & 6.80 & 6.93 & 7.90 & 8.64 & 8.95 & 7.74 & 7.13 \\
\hline 14 & $\mathrm{f}(\mathrm{n} / \mathrm{N})=0,1+0,9 \mathrm{n} / \mathrm{N}$ & & Hitungan & 0.63 & 0.71 & 0.85 & 0.85 & 0.87 & 0.90 & 0.90 & 0.96 & 0.97 & 0.94 & 0.76 & 0.67 \\
\hline 15 & Kecepatan Angin (u) & $\mathrm{m} / \mathrm{s}$ & Data & 2.30 & 2.34 & 2.21 & 2.06 & 2.04 & 2.52 & 2.82 & 2.94 & 2.77 & 2.70 & 2.34 & 2.00 \\
\hline 16 & $\mathrm{f}(\mathrm{u})=0,27\{1+(\mathrm{ux} 0,864)\}$ & & Hitungan & 0.81 & 0.82 & 0.79 & 0.75 & 0.75 & 0.86 & 0.93 & 0.96 & 0.92 & 0.90 & 0.82 & 0.74 \\
\hline 17 & $\mathrm{Rn} 1=\mathrm{f}(\mathrm{T}) \times \mathrm{xf}(\mathrm{ed}) \mathrm{xf}(\mathrm{n} / \mathrm{N})$ & & Hitungan & 1.00 & 1.13 & 1.34 & 1.44 & 1.48 & 1.75 & 1.73 & 1.93 & 1.91 & 1.71 & 1.24 & 1.06 \\
\hline 18 & $\mathrm{Rn}=\mathrm{Rns}-\mathrm{Rn} 1$ & $\mathrm{~mm} / \mathrm{hari}$ & Hitungan & 5.83 & 6.31 & 6.80 & 6.13 & 5.53 & 5.05 & 5.20 & 5.97 & 6.73 & 7.24 & 6.50 & 6.07 \\
\hline 19 & Angka Koreksi (c) & & Tabel & 1.1 & 1.1 & 1 & 1 & 0.95 & 0.95 & 1 & 1 & 1.1 & 1.1 & 1.15 & 1.15 \\
\hline 20 & Eto & $\mathrm{mm} /$ hari & Hitungan & 5.83 & 6.27 & 6.13 & 5.82 & 5.26 & 5.20 & 5.90 & 6.87 & 8.15 & 8.59 & 7.57 & 6.47 \\
\hline
\end{tabular}

Untuk mengetahui kebutuhan air selama penyiapan lahan digunakan persamaan (1). Contoh perhitungan penyiapan lahan pada bulan Januari adalah sebagai berikut.

$$
\begin{aligned}
& \text { Eo }=\text { Eto } \times 1,10=5,83 \times 1,10=6,42 \\
& \mathrm{P}=2 \mathrm{~mm} / \mathrm{hari} \\
& \mathrm{M}=\mathrm{Eo}+\mathrm{P}=8,42 \mathrm{~mm} / \mathrm{hari} \\
& \mathrm{T}=31 \text { hari } \\
& \mathrm{S}=\text { Kebutuhan air untuk penjenuhan dengan } 50 \mathrm{~mm} \text {. jadi } 250+50=300 \mathrm{~mm} \\
& \mathrm{k}=\frac{7,86 \mathrm{~mm} / \text { hari } \times 31 \text { hari }}{300 \mathrm{~mm}}=0,87 \\
& \mathrm{LP}=\frac{\mathrm{M}^{\mathrm{k}} \mathrm{e}^{\mathrm{m}}}{\left(\mathrm{e}^{\mathrm{k}}-1\right)}=\frac{7,86 \times 2,7192^{0,76}}{\left(2,7192^{0,76}-1\right)}=14,49 \mathrm{~mm} / \mathrm{hari}
\end{aligned}
$$

\begin{tabular}{|c|c|c|c|c|c|c|c|c|c|c|c|c|c|c|}
\hline \multirow{2}{*}{ No } & \multirow{2}{*}{ Uraian } & \multirow{2}{*}{ Satuan } & \multicolumn{12}{|c|}{ Bulan } \\
\hline & & & Jan & Feb & Mar & Apr & Mei & Jun & Jul & Ags & Sep & Okt & Nov & Des \\
\hline 1 & Eto & $\mathrm{mm} / \mathrm{hr}$ & 5.83 & 6.27 & 6.13 & 5.82 & 5.26 & 5.20 & 5.90 & 6.87 & 8.15 & 8.59 & 7.57 & 6.47 \\
\hline 2 & $E o=$ Eto $\times 1,10$ & $\mathrm{~mm} / \mathrm{hr}$ & 6.42 & 6.90 & 6.74 & 6.40 & 5.79 & 5.72 & 6.49 & 7.55 & 8.96 & 9.45 & 8.33 & 7.12 \\
\hline 4 & $M=E o+P$ & $\mathrm{~mm} / \mathrm{hr}$ & 8.42 & 8.90 & 8.74 & 8.40 & 7.79 & 7.72 & 8.49 & 9.55 & 10.96 & 11.45 & 10.33 & 9.12 \\
\hline 5 & $T$ & $\mathrm{Hr}$ & 31 & 28 & 31 & 30 & 31 & 30 & 31 & 30 & 31 & 31 & 30 & 31 \\
\hline 6 & $S$ & $\mathrm{Mm}$ & 300 & 300 & 300 & 300 & 300 & 300 & 300 & 300 & 300 & 300 & 300 & 300 \\
\hline 7 & $k=M T / S$ & & 0.87 & 0.83 & 0.90 & 0.84 & 0.80 & 0.77 & 0.88 & 0.96 & 1.13 & 1.18 & 1.03 & 0.94 \\
\hline 8 & $L P=\left(M e^{k}\right) /\left(e^{k}-1\right)$ & $\mathrm{mm} / \mathrm{hr}$ & 14.49 & 15.77 & 14.70 & 14.78 & 14.08 & 14.35 & 14.53 & 15.52 & 16.17 & 16.50 & 16.03 & 14.94 \\
\hline
\end{tabular}

Sehingga dari perhitungan di atas diperoleh kebutuhan air pada bulan Januari adalah 14,14 liter air per meter ${ }^{2}$ per harinya. Sedangkan untuk perhitungan bulan yang lain juga menggunakan langkah-langkah di atas, adapun hasil perhitungannya disajikan pada tabel 3 .

Tabel 3. Perhitungan Kebutuhan Air untuk Penyiapan Lahan 
Peramalan debit air yang dibutuhkan untuk penyiapan lahan pada periode berikutnya dapat menggunakan innformasi data pada Tabel 3, Yaitu LP sebagai variabel terikat $(Y)$ dan bulan $(X)$ sebagai variabel bebasnya. Sehingga dengan mengunakan SPSS sebaran pola datanya dapat didekati dengan persamaan kubik dimodelkan seperti Gambar 1.

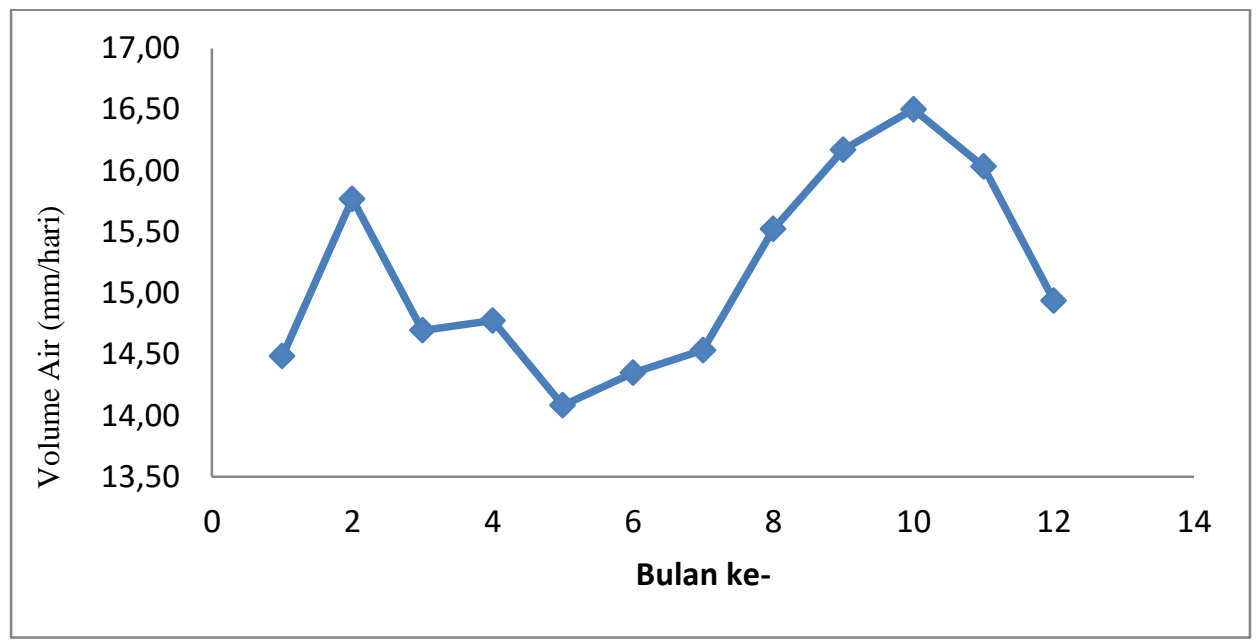

Gambar 1. Grafik Kebutuhan Air untuk Penyiapan lahan tahun 2019

Selanjutnya berdasarkan informasi data pada tabel 3 dan model sebaran data berdasarkan gambar 1 maka dapat ditentukan model peramalan dengan metode siklis dengan melakukan rekapitulasi perhitungan marameter peramalan yang disajikan pada tabel 4.

Tabel 4.Perhitungan Metode Siklis

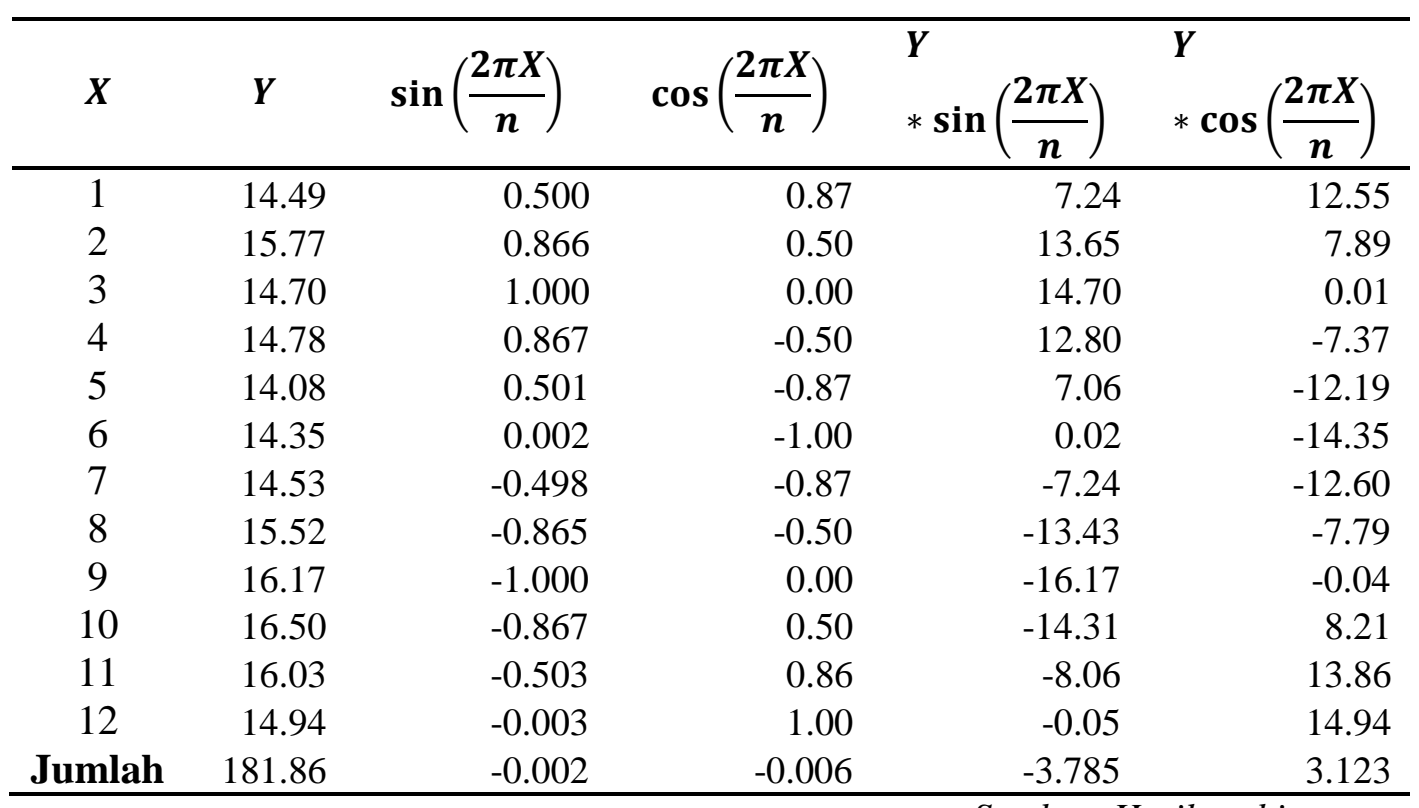


Sehingga diperoleh fungsi peramalan sebagai berikut.

$$
Y=15,155-0,631 \sin \frac{2 \pi X}{n}+0,521 \cos \frac{2 \pi X}{n}
$$

Dari model peramalan peramalan yang diperoleh pada persamaan (5) tersebut dapat disusun peramalan debit kebutuhan air irigasi penyiapan lahan pada periode berikutnya, yaitu disajikan pada tabel 4 .

Tabel 4. Peramalan kebutuhan air untuk penyiapan lahan tahun 2020

\begin{tabular}{cc}
\hline Bulan $(\boldsymbol{X})$ & $\begin{array}{c}\text { Kebutuhan Air } \\
\text { Penyiapan Lahan } \\
(\boldsymbol{Y})\end{array}$ \\
\hline Januari & 15.294 \\
Februari & 14.872 \\
Maret & 14.527 \\
April & 14.349 \\
Mei & 14.388 \\
Juni & 14.631 \\
Juli & 15.016 \\
Agustus & 15.437 \\
September & 15.784 \\
Oktober & 15.962 \\
November & 15.924 \\
Desember & 15.681 \\
\hline
\end{tabular}

Sumber: Hasil perhitungan

Dengan menggunakan persamaan (4) maka dapat diketahui tingkat akurasi nilai peramalan yang telah diperoleh dengan metode siklis, yaitu diperoleh tingkat akurasi sebesar $99 \%$.

\section{Kesimpulan}

Berdasarkan penelitianyang telah dilakukan maka diperoleh:

1. Informasi kebutuhan air untuk penyiapan lahan pertanian di daerah irigasi bendungan Batu Bulan kecamatan Moyo Hulu pada tahun 2019. Dimana kebutuhan debit air maksimum pada bulan Oktober yaitu sebesar 16.50 $\mathrm{mm} /$ hari atau 16.50 liter $/ \mathrm{m}^{2}$ per harinya, Sedangkan kebutuhan air minimum pada bulan Mei $14,08 \mathrm{~mm} /$ hari atau liter $/ \mathrm{m}^{2}$ per harinya.

2. Sedangkan hasil peramalan kebutuhan air untuk penyiapan lahan pertanian tahun 2020 dengan dengan menggunakan metode siklis dengantingkat akurasi 99\% diperoleh kebutuhan debit air maksimum pada bulan Oktober yaitu sebesar $15.962 \mathrm{~mm} /$ hari atau $15.962 \mathrm{liter} / \mathrm{m}^{2}$ per harinya, Sedangkan kebutuhan air minimum pada bulan Mei $14.388 \mathrm{~mm} / \mathrm{hari}$ atau liter $/ \mathrm{m}^{2}$ per harinya.

3. Tingkat kebutuhan air untuk penyiapan lahan pada bulan Oktober sangkat tinggi karena pada bulan tersebut merupakan puncak musim kemarau. 


\section{Ucapan Terimakasih}

Tim peneliti mengucapkan terima kasih kepada Ditlitabmas Dirjen Dikti Kementerian dan Kebudayaan yang telah mendanai penelitian ini, serta menyampaikan terimakasih kepada Dinas BMKG kabupaten Sumbawa yang telah memberikan informasi data klimatologi. Semoga penelitianini dapat bermanfaat.

\section{Daftar Pustaka}

[1] Priyonugroho, A. 2014. Analisis Kebutuhan Air Irigasi (Studi Kasus Pada Daerah Irigasi Sungai Air Keban Kabupaten Empat Lawang. Jurnal Teknik Sipil dan Lingkungan. 02 (03): 457-470.

[2] Rokhma, N. 2018. Penyiapan Pangan dengan Irigasi Hemat Air. Kanisus: Yogyakarta.

[3] Rozi, F. 2016. Metode Siklis dan Adaptive Neuro Fuzzy Inference System untuk Peramalan Cuaca. Jurnal Ilmiah Pendidikan Informatika. 01 (01): 7 13.

[4] Sayuti. 2014. Aplikasi Perhitungan Metode Peramalan Produksi Pada CV. $X$. Teknovasi. 01 (02): 35-43 